\title{
Tracking continental-scale modification of the Earth's mantle using zircon megacrysts
}

\author{
J. Woodhead ${ }^{1 *}$, J. Hergt ${ }^{1}$, A. Giuliani,1,2, D. Phillips ${ }^{1}$, R. Maas ${ }^{1}$
}

Abstract

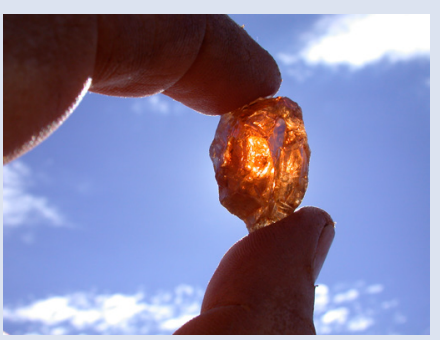

Metasomatism, the chemical alteration of rocks by a variety of melts and fluids, has formed a key concept in studies of the Earth's mantle for decades. Metasomatic effects are often inferred to be far-reaching and yet the evidence for their occurrence is usually based upon individual hand specimens or suites of rocks that display considerable heterogeneity. In rare cases, however, we are offered insights into larger-scale chemical modifications that occur in the mantle. Here we utilise the Lu-Hf systematics of zircon megacrysts erupted in kimberlite magmas to discern two temporally and compositionally discrete metasomatic events in the mantle beneath southern Africa, each having an influence extending over an area exceeding one million $\mathrm{km}^{2}$. These data provide unambiguous evidence for metasomatic processes operating at continental scales and seemingly unperturbed by the age and composition of the local lithospheric mantle. The most recent of these events may be associated with the major Jurassic-Karoo magmatism in southern Africa.

Received 8 December 2016 | Accepted 22 May 2017 | Published 10 July 2017

\section{Introduction}

Metasomatism is an important process generating regions of mantle enriched in volatile and incompatible elements that may subsequently melt, giving rise to a range of magma types. The spatial extent of metasomatic processes is poorly understood because geographically extensive studies of relevant metasomatic minerals with known ages are rare. Zircon megacrysts, an uncommon, large (cm-sized) and somewhat unusual mineral occurrence, recovered during the processing of kimberlites to extract diamonds, may fill this gap. Their trace element patterns (Valley et al., 1998, Belousova et al., 2002) and low $\delta^{18} \mathrm{O}$ (Page et al., 2007) indicate that they are not of crustal origin, but crystallised within the mantle and experienced only minimal chemical interaction with the host magmas that transported them to the surface. While details of their petrogenesis (and the origin of megacryst suites more broadly) remain a subject of active research, there is agreement that zircon megacrysts are produced by metasomatic melts in some way related to kimberlite magmas (e.g., Kinny et al., 1989; Nowell et al., 2004; Page et al., 2007). They record precise $\mathrm{U}-\mathrm{Pb}$ ages and initial ${ }^{176} \mathrm{Hf} /{ }^{177} \mathrm{Hf}$ isotope ratios providing important constraints on the age and nature of the metasomatic events occurring in their mantle sources. We present the first geographically-extensive survey of Hf-isotope and U-Pb age distributions for zircon megacrysts in southern African kimberlites, representing widely spaced intrusions spanning both cratonic (Kaapvaal, Zimbabwe) and non-cratonic settings (Fig. 1). We also report the first $\mathrm{Nd}$-isotope data for zircon megacrysts.

\section{Results}

Zircons have very low $\mathrm{Lu} / \mathrm{Hf}$ ratios and thus preserve the initial ${ }^{176} \mathrm{Hf} /{ }^{177} \mathrm{Hf}$ of their source metasomatic melts (Table 1 ; full data in Tables S-1 and S-2). Our results reveal an entirely unexpected first order observation; that is, remarkable largescale isotopic homogeneity among southern African zircon megacrysts (Fig. 2a) across lithospheric domains with widely differing ages (e.g., Pearson and Wittig, 2014). Although a restricted isotopic range in Hf-isotopes has been noted previously in a much smaller dataset of kimberlite megacrysts from this area (Griffin et al., 2000), our analyses show near identical isotopic compositions in samples derived from numerous intrusions distributed across a region of $>1$ million $\mathrm{km}^{2}$.

The data form two homogeneous yet distinct compositional groups, which we term A and B (Fig. 2a); a distinction also mirrored in the new Nd-isotope data (Table 1). Some kimberlite pipes contain both zircon groups (e.g., Wesselton, Koffiefontein), as previously reported for the Orapa and Jwaneng kimberlites (Kinny et al., 1989, Griffin et al., 2000). Remarkably, the subtle variations in ${ }^{176} \mathrm{Hf} /{ }^{177} \mathrm{Hf}$ and ${ }^{143} \mathrm{Nd} /{ }^{144} \mathrm{Nd}$ in zircons of the larger Group A correlate with age and may reflect radiogenic ingrowth in the source of the metasomatic zircon parent melts (Fig. 2b, 2c). Although the ${ }^{176} \mathrm{Hf} /{ }^{177} \mathrm{Hf}$ - age correlation is largely defined by the off-craton samples that show the greatest range of ages, it remains true that the cluster of on-craton samples also lies along this array. All results from this study plot below the Nd-Hf isotope mantle array (Fig. 3).

\footnotetext{
1. School of Earth Sciences, The University of Melbourne, VIC 3010, Australia

* Corresponding author (email: jdwood@unimelb.edu.au)

2. Department of Earth and Planetary Sciences, Macquarie University, North Ryde, NSW 2019, Australia
} 
Group A zircons yield precise and concordant $\mathrm{U}-\mathrm{Pb}$ ages which generally approximate the (usually less precise) age estimates of their kimberlite hosts (Table 1, Figs. 2d and S-1). In contrast, U-Pb systematics for Group B zircons are disturbed (Fig. S-1), precluding accurate dating, and suggesting a more protracted history.

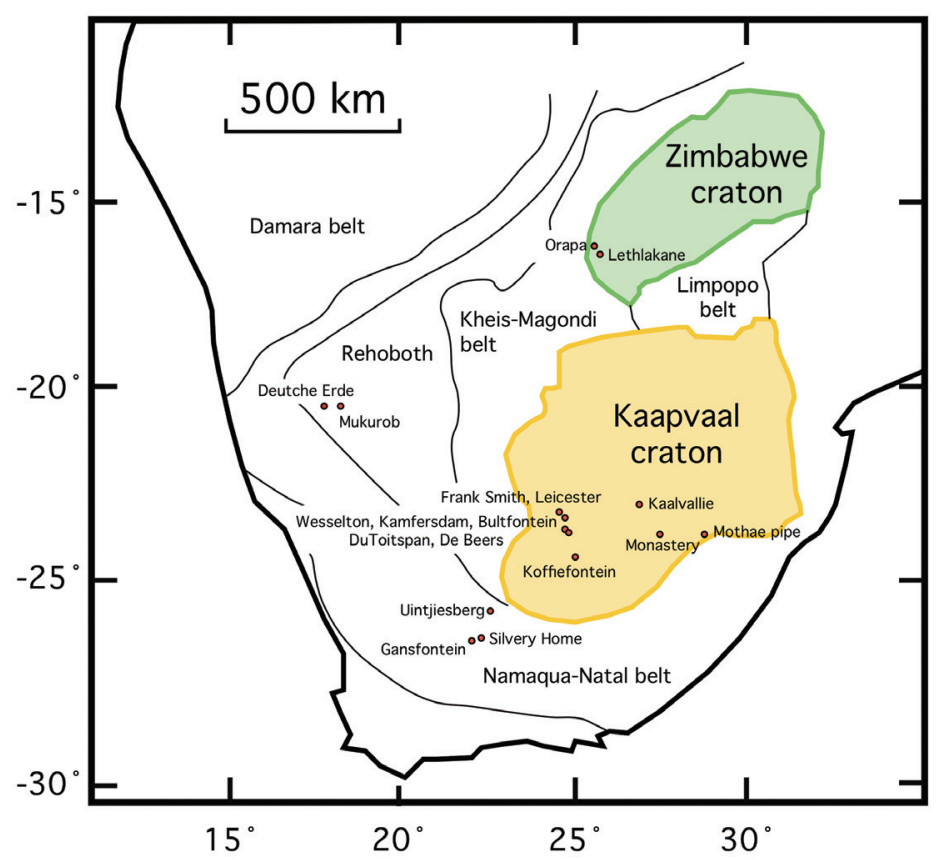

Figure 1 Schematic map of southern Africa showing kimberlite localities for zircon megacrysts analysed in this and previous studies. The major tectonic domains are also included.

Table 1 Summary data. U-Pb age, $\mathrm{Hf}$ and $\mathrm{Nd}$-isotope data for megacryst zircons. All data from this study unless otherwise noted: $\mathrm{G}=$ Griffin et al. (2000), $\mathrm{N}=$ Nowell et al. (2004). Where multiple solution analyses are shown from the same kimberlite body these represent different zircon megacrysts.

\begin{tabular}{|c|c|c|c|c|c|c|c|c|c|c|c|c|}
\hline \multirow[b]{2}{*}{ Host } & \multicolumn{3}{|c|}{ IN SITU ANALYSES } & \multicolumn{9}{|c|}{ SOLUTION ANALYSES } \\
\hline & $\begin{array}{c}\mathrm{U} / \mathrm{Pb} \text { age } \\
(\mathrm{Ma})\end{array}$ & 2 sigma & $\begin{array}{l}{ }^{176} \mathrm{Hf} / \\
{ }^{177} \mathrm{Hf}\end{array}$ & 2 sigma & Sm ppm & Nd ppm & $\begin{array}{l}{ }^{143} \mathrm{Nd} / \\
{ }^{144} \mathrm{Nd}_{\mathrm{m}}\end{array}$ & $\begin{array}{l}{ }^{143} \mathrm{Nd} / \\
{ }^{144} \mathrm{Nd}_{\mathrm{i}}\end{array}$ & $\begin{array}{l}\text { Epsilon } \\
\mathrm{Nd}_{\mathrm{i}}\end{array}$ & $\begin{array}{l}{ }^{176} \mathrm{Hf} / \\
{ }^{177} \mathrm{Hf}_{\mathrm{m}}\end{array}$ & $\begin{array}{l}{ }^{176} \mathrm{Hf} / \\
{ }^{177} \mathrm{Hf}_{\mathrm{i}}\end{array}$ & $\begin{array}{c}\text { Epsilon } \\
\text { Hf }_{\mathrm{i}}\end{array}$ \\
\hline Mukurob & $\begin{array}{l}57.62 \\
57.62\end{array}$ & 0.57 & 0.28281 & 0.00002 & $\begin{array}{l}0.734 \\
0.713\end{array}$ & $\begin{array}{l}0.565 \\
0.547\end{array}$ & $\begin{array}{l}0.51302 \\
0.51306\end{array}$ & $\begin{array}{l}0.51273 \\
0.51277\end{array}$ & $\begin{array}{l}3.30 \\
4.05\end{array}$ & $\begin{array}{l}0.28284 \\
0.28283\end{array}$ & $\begin{array}{l}0.28284 \\
0.28283\end{array}$ & $\begin{array}{l}3.11 \\
2.95\end{array}$ \\
\hline Deutche Erde & 67.94 & 0.72 & 0.28277 & 0.00003 & & & & & & & & \\
\hline Silvery Home & 79.60 & 0.24 & 0.28270 & 0.00001 & & & & & & & & \\
\hline Wesselton & 86.36 & 0.45 & 0.28274 & 0.00006 & & & & & & & & \\
\hline $\begin{array}{l}\text { Wesselton - } \\
\text { Group B }\end{array}$ & unknown & & 0.28222 & 0.00001 & & & & & & & & \\
\hline De Beers & 87.26 & 0.69 & 0.28264 & 0.00001 & 1.332 & 1.087 & 0.51307 & 0.51265 & 2.42 & 0.28270 & 0.28270 & -1.23 \\
\hline Du Toitspan & 87.80 & 1.20 & 0.28275 & 0.00001 & & & & & & & & \\
\hline \multirow[t]{2}{*}{ Monastery } & 88.69 & 0.50 & 0.28272 & 0.00001 & & & & & & & & \\
\hline & $\begin{array}{l}88.69 \\
88.69\end{array}$ & & $\begin{array}{l}0.282725 \\
0.282703\end{array}$ & $\begin{array}{l}0.00001 \\
0.00000\end{array}$ & & & & & & & & \\
\hline Lethlakane & 92.01 & 0.67 & 0.28273 & 0.00001 & & & & & & & & \\
\hline \multirow[t]{3}{*}{ Bultfontein } & 93.96 & 0.49 & 0.28269 & 0.00001 & 0.314 & 0.294 & 0.51298 & 0.51259 & 1.48 & 0.28270 & 0.28270 & -0.92 \\
\hline & 93.96 & & & & 0.446 & 0.477 & 0.51295 & 0.51261 & 1.78 & 0.28269 & 0.28269 & -1.32 \\
\hline & 93.96 & & & & 0.371 & 0.306 & 0.51305 & 0.51260 & 1.56 & 0.28270 & 0.28270 & -1.06 \\
\hline \multirow[t]{2}{*}{ Koffiefontein } & 94.16 & 0.53 & 0.28271 & 0.00001 & 0.316 & 0.217 & 0.51316 & 0.51262 & 2.02 & 0.28274 & 0.28274 & 0.44 \\
\hline & 94.16 & & & & 0.625 & 0.438 & 0.51320 & 0.51267 & 3.16 & 0.28276 & 0.28276 & 1.13 \\
\hline $\begin{array}{l}\text { Koffiefontein - } \\
\text { Group B }\end{array}$ & unknown & & 0.28227 & 0.00005 & 0.232 & 0.279 & 0.51323 & unknown & unknown & 0.28228 & unknown & unknown \\
\hline \multirow[t]{3}{*}{ Orapa - Group A } & 96.55 & 0.73 & 0.28273 & 0.00001 & & & & & & & & \\
\hline & 96.55 & & 0.28275 & 0.00001 & & & & & & & & \\
\hline & 96.55 & & 0.28271 & 0.00001 & & & & & & & & \\
\hline \multirow[t]{3}{*}{ Orapa - Group B } & unknown & & 0.28232 & 0.00003 & & & & & & & & \\
\hline & unknown & & 0.28233 & 0.00002 & & & & & & & & \\
\hline & unknown & & 0.282254 & 0.00001 & & & & & & & & \\
\hline Uintjesberg & 103.42 & 0.74 & 0.28266 & 0.00002 & & & & & & & & \\
\hline Frank Smith & 114.48 & 0.83 & 0.28260 & 0.00001 & & & & & & & & \\
\hline Kaalvalie & & & 0.282751 & 0.00001 & & & & & & & & \\
\hline Kamfersdam & & & 0.282721 & 0.00001 & & & & & & & & \\
\hline Mothae & & & 0.28257 & 0.00005 & & & & & & & & \\
\hline Gansfontein & & & 0.282709 & 0.00001 & & & & & & & & \\
\hline Leicester & & & 0.28257 & 0.00005 & & & & & & & & \\
\hline
\end{tabular}



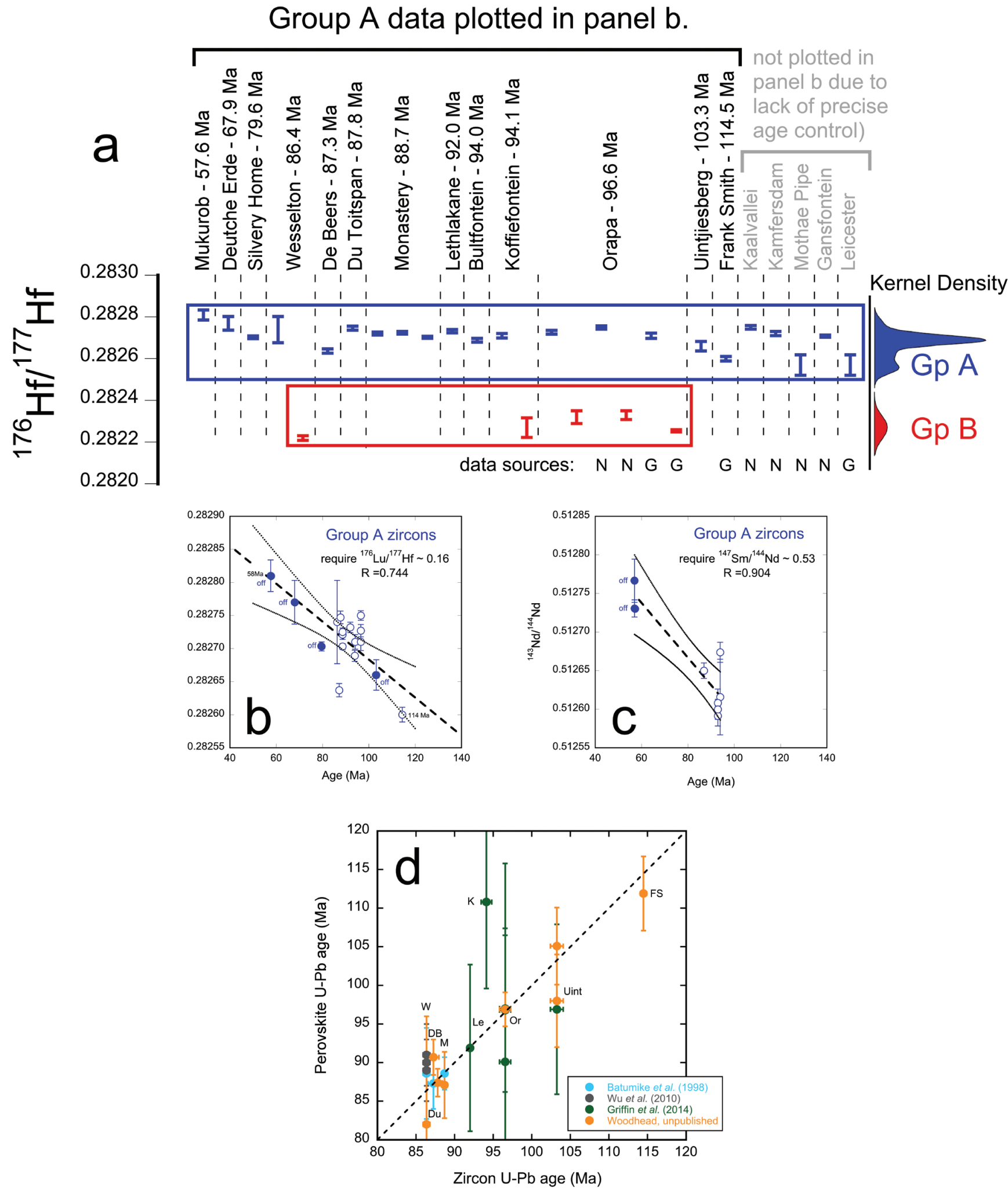

Figure 2 Age and isotopic composition data for zircon megacrysts. (a) Zircon Hf-isotope data showing a natural compositional subdivision into two distinct groups, further illustrated by Kernel Density estimates. Note the remarkable isotopic homogeneity within each group despite large variations in geographic location and age. All data from this study unless marked: $\mathrm{N}=\mathrm{Nowell}$ et al. (2004), G = Griffin et al. (2000). (b) Inset showing a statistically significant correlation between zircon ${ }^{176} \mathrm{Hf} /{ }^{177} \mathrm{Hf}$ composition and age. Only zircons for which precise U-Pb Concordia ages are available are used to construct this plot. Literature data with less precise age determinations (greyed out in $2 a$ ) are excluded. (c) An equivalent plot to $2 b$ for ${ }^{143} \mathrm{Nd} /{ }^{144} \mathrm{Nd}$ isotope variations. (d) $A$ comparison between kimberlite U-Pb perovskite ages, widely used to estimate the timing of magmatism, and U-Pb zircon megacryst ages from the same intrusion. Megacryst ages clearly approximate those of the kimberlite host, at least within the resolution of the perovskite technique. 


\section{Discussion}

Isotopic constraints. Our results provide a consistent picture of megacryst parental melts which tapped an isotopically homogeneous source extending over hundreds of kilometres, and encompassing a time interval of nearly $70 \mathrm{Myr}$, the range of $\mathrm{U}-\mathrm{Pb}$ ages (114-56 Ma) recorded by the zircons. The apparent ${ }^{176} \mathrm{Hf} /{ }^{177} \mathrm{Hf}$ - age relationship defined by the Group A zircons places important constraints on the nature and evolution of their mantle source(s). To produce such a correlation these source rocks must have been relatively homogeneous initially and subsequently evolved rapidly with a strongly super-chondritic ${ }^{176} \mathrm{Lu} /{ }^{177} \mathrm{Hf}$ ratio $\left(\sim 0.16\right.$, Fig. 2 b). The initial ${ }^{143} \mathrm{Nd} /{ }^{144} \mathrm{Nd}$ values for Group A zircon megacrysts also correlate with age (Fig. 2c), consistent with a source that evolved with a moderate-high ${ }^{147} \mathrm{Sm} /{ }^{144} \mathrm{Nd}$ ratio of $\sim 0.53$ (although both parentdaughter ratios are poorly defined, based on the paucity of the data). Importantly, prior to rapid radiogenic ingrowth, the initial source rock composition must have been located off the mantle-array, displaced to lower ${ }^{176} \mathrm{Hf} /{ }^{177} \mathrm{Hf}$ for a given ${ }^{143} \mathrm{Nd} /{ }^{144} \mathrm{Nd}$ (Fig. 3). This also provides important insights into both the nature of the original mantle source rocks and the metasomatic fluid that modified them.

We postulate that the mantle source rocks originally had a protracted history of unusually low Lu/Hf and Sm/Nd and developed initial ${ }^{176} \mathrm{Hf} /{ }^{177} \mathrm{Hf}$ and ${ }^{143} \mathrm{Nd} /{ }^{144} \mathrm{Nd}$ that are low relative to MORB mantle (i.e. 'enriched mantle', Fig. 3). Subsequent metasomatism of these source rocks not only drastically raised $\mathrm{Lu} / \mathrm{Hf}$ to drive rapid ${ }^{176} \mathrm{Hf}$ ingrowth for at least $~ 70 \mathrm{Myr}$ (Fig. 2b) but must also have had a) low Hf contents to preserve the original unradiogenic ${ }^{176} \mathrm{Hf} /{ }^{177} \mathrm{Hf}$ signature of the protolith but b) sufficient $\mathrm{Nd}$ to modify the ${ }^{143} \mathrm{Nd} /{ }^{144} \mathrm{Nd}$ to values more typical of OIB. Metasomatism therefore decoupled $\mathrm{Hf}$ from $\mathrm{Nd}$ (and presumably $\mathrm{Sr}$ ) isotope compositions to generate source rocks, and ultimately zircon megacrysts, with compositions to the right of the Nd-Hf mantle array (Fig. 3).

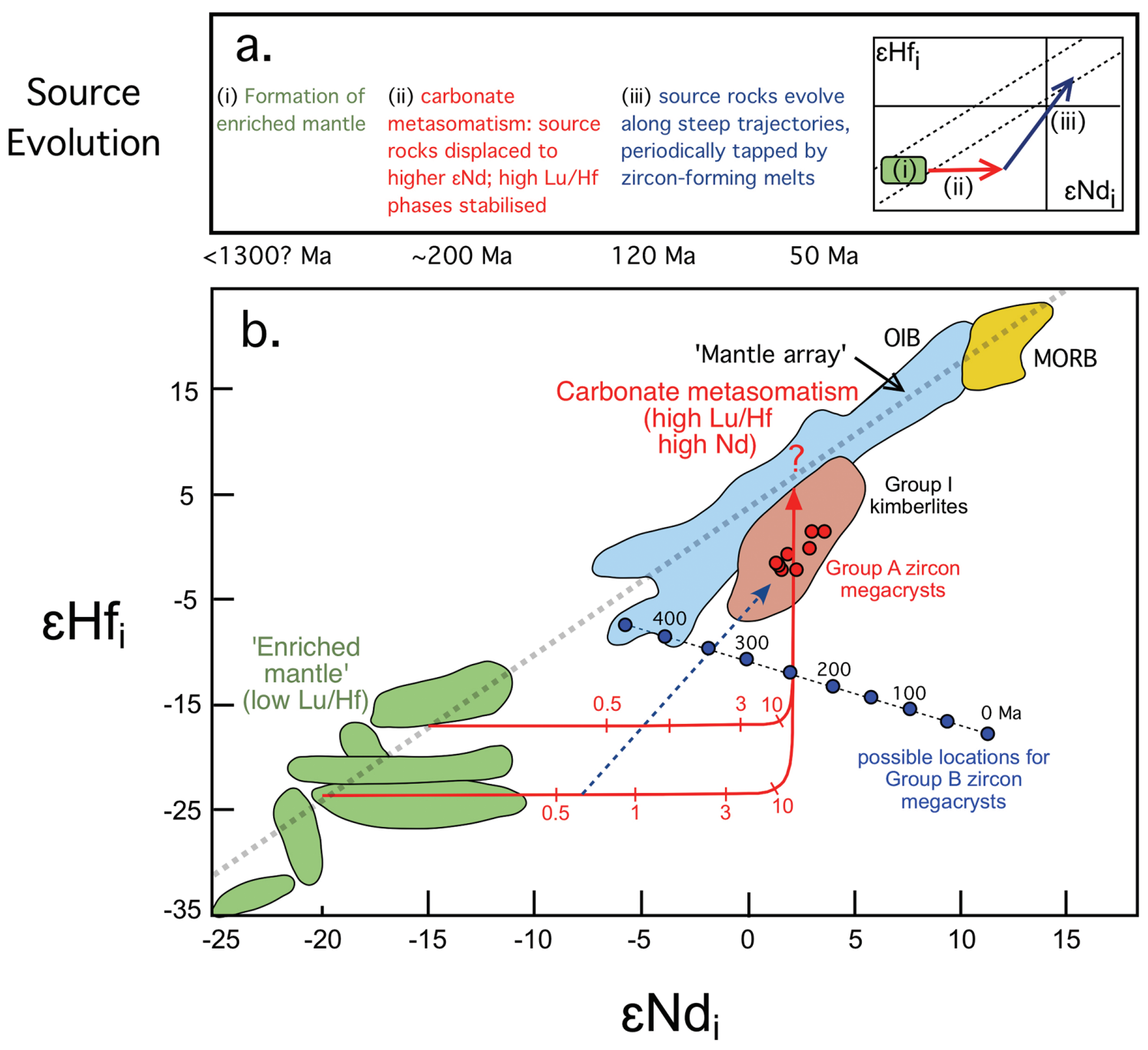

Figure 3 A three-step process, summarised in panel (a), proposed to explain the variations within the $\mathrm{Nd}$ - and $\mathrm{Hf}$-isotope arrays for zircon megacrysts. (i) A source with prolonged depletion in Lu/Hf and $\mathrm{Sm} / \mathrm{Nd}$ evolves to highly negative $\varepsilon \mathrm{Nd}$ and $\varepsilon \mathrm{Hf}$ compositions, depicted here as the source of various lamproites (from Davies et al., 2006 and references therein) (ii) A carbonate melt, with an isotopic composition similar to OIB pervades this source, preserving the $\mathrm{Hf}$ isotopic composition of the source owing to its low $\mathrm{Hf}$ content, but overprinting the source rocks with a Nd isotope composition more typical of OIB. In addition to displacing the isotopic composition of the source rocks off the mantle array, this metasomatic process stabilises high Lu/Hf phases. (iii) With time, the isotopic compositions of the source evolve along steep trajectories (shown by the dashed blue arrow in panel (b) owing to their now elevated $\mathrm{Lu} / \mathrm{Hf}$ and $\mathrm{Sm} / \mathrm{Nd}$ ratios. Parental melts to zircon megacrysts (red circles for Group A zircons, blue circles represent the possible locations of initial $\varepsilon_{\mathrm{Hf}}-\varepsilon_{\mathrm{Nd}}$ for Group B zircons, calculated for a range of potential ages) tap this source periodically, as it evolves to higher $\varepsilon_{\mathrm{Nd}}$ and $\varepsilon_{\mathrm{Hf}}$ with time. Mantle array line from Vervoort et al. (1999). 
The lack of precise age control precludes a similar assessment for the much smaller Group B zircon dataset. Nevertheless, the fact that zircons sharing such similar isotopic characteristics were erupted across broad areas of southern Africa (i.e. Wesselton and Koffiefontein in the Kimberley area, South Africa, and Orapa in Botswana), supports the existence of a second widespread event in the mantle beneath the southern African sub-continent.

Towards a genetic model. The potential link between carbonate metasomatism and kimberlite/megacryst genesis has been made often but typically based upon petrographic or experimental evidence (e.g., Giuliani et al., 2012; Russell et al., 2012). Carbonate melts are the least viscous of known terrestrial magma types (Dobson et al., 1996) and may thus have the ability to pervade large regions of the mantle. The work of Bizimis et al. (2003) also suggests that carbonate fractions of carbonatites have low Hf contents, high Lu/Hf and decoupled Nd-Hf isotope systematics. Accordingly, we explore a model in which a carbonate melt infiltrates mantle with compositions at the low $\varepsilon_{\mathrm{Hf}^{-}} \varepsilon_{\mathrm{Nd}}$ (enriched) end of the Hf-Nd mantle array, similar to the source of lamproite magmas which originate in enriched lithospheric mantle (Nowell et al., 1998, 2004). At small degrees of metasomatic addition, the expected mixing trajectory is almost horizontal as the inferred carbonate melt has high $\mathrm{Nd} / \mathrm{Hf}$ and $\varepsilon_{\mathrm{Nd}}$ relative to the enriched mantle source (Fig. 3). The marked increase in Lu/Hf of this carbonate-metasomatised lithospheric mantle then drives a rapid rise in ${ }^{176} \mathrm{Hf} /{ }^{177} \mathrm{Hf}$ (producing very steep trends in Nd-Hf isotope space) with time. Garnet may have been among the newlygrown high-Lu phases important in establishing the high Lu/ Hf ratio of the metasomatised source. As this source evolves and is sampled by kimberlite magmatism during the Jurassic and Cretaceous (producing zircon megacrysts), the isotope vs. age covariation is revealed (blue dotted arrow, Fig. 3).

Location and timing of metasomatism. The Hf isotope vs. age trend observed in the megacryst zircons is consistent with isotopic evolution under closed system conditions for $\sim 70$ Myr. While this could be readily achieved in the lithosphere, the observed trend crosses cratonic boundaries, and would therefore require that metasomatism efficiently overprinted any pre-existing compositional heterogeneity. A location at or below the lithosphere-asthenosphere boundary is also plausible, consistent with evidence that at least some initial kimberlite melts originate from sub-lithospheric depths (Tappe et al., 2013; Pearson et al., 2014). Our data do not preclude either possibility.

The occurrence of near-homogeneous ${ }^{176} \mathrm{Hf} /{ }^{177} \mathrm{Hf}$ in megacryst zircons across two cratons (Kaapvaal and Zimbabwe) and the surrounding Proterozoic requires the inferred metasomatic processes to postdate final tectonic assembly of these crustal domains. This suggests the source of Group A zircons postdates the $1300 \mathrm{Ma}$ amalgamation of the Kaapvaal craton and the Namaqua-Natal belt (Eglington, 2006), the youngest terrane with Cretaceous kimberlites; a younger limit is provided by the age of the oldest host kimberlite, the $114 \mathrm{Ma}$ Frank Smith pipe. Importantly, the rapid isotopic evolution of the modified mantle source required by the zircon data, make it unlikely that the metasomatic event occurred more than a few hundred million years ago.

Although the timing of Group B zircon formation is unknown (because their $\mathrm{U}-\mathrm{Pb}$ systematics have been disturbed) some limits can be placed on their age (and hence the minimum age of metasomatism of their source), by calculating the initial $\varepsilon_{\mathrm{Hf}}-\varepsilon_{\mathrm{Nd}}$, for a range of hypothetical ages. Using the single Group B zircon for which we have Nd data (Koffiefontein), ages $<250 \mathrm{Ma}$ or $>>500 \mathrm{Ma}$ are highly improbable because the resultant zircon initial $\varepsilon_{\mathrm{Hf}^{-}} \varepsilon_{\mathrm{Nd}}$ would be unfeasible (Fig. 3). On this basis, we speculate an age for the Group B zircons of between 250 and $500 \mathrm{Ma}$, with metasomatic alteration of their mantle source being somewhat older.

\section{Concluding Remarks}

Our new Hf-isotope data provide clear evidence for a discrete metasomatic event in the southern Africa mantle operating at a continent-wide scale between $114 \mathrm{Ma}$ and several hundred million years ago, and subsequently sampled by separate kimberlite eruptions over a period of at least 70 Myr. The possibility of a link between such large-scale mantle metasomatism and formation of the Karoo large igneous province has previously been suggested (Konzett et al., 1998; Ernst and Bell, 2010), and would be consistent with the very large thermal and magmatic perturbation resulting from Karoo activity. New geochronological data for metasomatised mantle xenoliths from the Kimberley kimberlites also suggest a direct association of these events (Giuliani et al., 2014). A link between widespread Karoo magmatism, modification of the southern African continental mantle, initiation of kimberlite magmatism, and megacryst formation therefore appears an intriguing possibility worthy of further study. A more disturbed and less sampled suite of zircon megacrysts supports the occurrence of a similar but older event.

\section{Acknowledgements}

We thank DeBeers for provision of the zircon samples that were originally collected by Dr John Bristow. JW and AG acknowledge funding from the Australian Research Council. Alan Greig is thanked for technical assistance.

\section{Editor: Graham Pearson}

\section{Additional Information}

Supplementary Information accompanies this letter at www. geochemicalperspectivesletters.org/article1727

Reprints and permission information are available online at http://www. geochemicalperspectivesletters.org/ copyright-and-permissions

Cite this letter as: Woodhead, J., Hergt, J., Giuliani, A., Phillips, D., Maas, R. (2017) Tracking continental-scale modification of the Earth's mantle using zircon megacrysts. Geochem. Persp. Let. 4, 1-6.

\section{References}

Batumike, J.M., Griffin, W.L., Belousova, E.A., Pearson, N.J., O'ReILly, S.Y., SHEE, S.R. (2008) LAM-ICPMS U-Pb dating of kimberlitic perovskite: Eocene-Oligocene kimberlites from the Kundelungu Plateau, D.R. Congo. Earth and Planetary Science Letters 267, 609-619.

Belousova, E.A., Griffin, W.L., O’Reilly, S.Y., Fischer, N.I. (2002) Igneous zircon: trace element composition as an indicator of source rock type. Contributions to Mineralogy and Petrology 143, 602-622.

BiZIMIS, M., SALTERS, V.J., DAWSON, J.B. (2003) The brevity of carbonatite sources in the mantle: evidence from Hf isotopes. Contributions to Mineralogy and Petrology 145, 281-300.

Davies, G.R., Stolz, A.J., Mahotkin, I.L., Nowell, G.M., Pearson, D.G. (2006) Trace element and Sr-Pb-Nd-Hf isotope evidence for ancient, fluid-dominated enrichment of the source of Aldan Shield lamproites. Journal of Petrology 47, 1119-1146. 
Dobson, D.P., Jones, A.P., Rabe, R., Sekine, T., Kurita, K., Taniguchi, T., Kondo, T., Kato, T., Shimomura, O., UrakaWA, S. (1996) In-situ measurement of viscosity and density of carbonate melts at high pressure. Earth and Planetary Science Letters 143, 207-215.

EgLington, B.M. (2006) Evolution of the Namaqua-Natal Belt, southern Africa - a geochonological and isotope geochemical review. Journal of African Earth Science 46, 93-111.

ERNST, R.E., BELL, K. (2010) Large igneous provinces (LIPs) and carbonatites. Mineralogy and Petrology 98, 55-76.

Giuliani, A., Kamenetsky, V.S., Phillips, D., Kendrick, M.A., Wyatt, B.A., GoemanN, K. (2012) Nature of alkali-carbonate fluids in the sub-continental lithospheric mantle. Geology 40, 967-970.

Giuliani, A., Kamenetsky, V.S., Phillips, D., Kendrick, M.A., Wyatt, B.A., GoemanN, K. (2014) LIMA U-Pb ages link lithospheric mantle metasomatism to Karoo magmatism beneath the Kimberley region, South Africa. Earth and Planetary Science Letters 401, 132-147.

Griffin, W.L., Pearson, N.J., Belousova, E., Jackson, S.E., VAN Achterburgh, E., O'Reilly, S.Y., Shee, S.R. (2000) The Hf isotope composition of cratonic mantle: LAM-MC-ICPMS analysis of zircon megacrysts in kimberlites. Geochimica et Cosmochimica Acta 64, 133-147.

Griffin, W.L., Batumike, J.M., Greau, Y., Pearson, N.J., Shee, S.R., O'REILlY, S.Y. (2014) Emplacement ages and sources of kimberlites and related rocks in southern Africa: $\mathrm{U}-\mathrm{Pb}$ ages and $\mathrm{Sr}-\mathrm{Nd}$ of groundmass perovskite. Contributions to Mineralogy and Petrology 168, 1032.

KinnY, P.D., Compston, W., Bristow, J.W., Williams, I.S. (1989) Archean mantle xenocrysts in a Permian kimberlite: two generations of kimberlitic zircon in Jwaneng DK2, southern Botswana. Geological Society of Australia Special Publication 14, 833-842.

Konzett, J., Armstrong, R.A., Sweeney, R.J., Compston, W. (1998) The timing of MARID metasomatism in the Kaapvaal mantle: an ion microprobe study of zircons from MARID xenoliths. Earth and Planetary Science Letters 160, 133-145.

Nowell, G.M., Pearson, D.G., Kempton, P.D., Irving, A.J., Turner, S. (1998). A Hf isotope study of lamproites: Implications for their origins and relationships to kimberlites.In: Gurney, J.J., Gurney, J.L., Pascoe, M.D., Richardson, S.H. (Eds.) 7th International Kimberlite Conference, Extended Abstracts. Red Roof Design, Capetown, 637-639.

Nowell, G.M., Pearson, D.G., Bell, D.R., Carlson, R.W., Smith, C.B., Kempton, P.D., Noble, S.R. (2004) Hf isotope systematics of kimberlites and their megacrysts: new constraints on their source regions. Journal of Petrology 45, 1583-1612.

Page, F.Z., Fu, B., Kita, N.T., Fournelle, J., Spicuzza, M.J., Schultz, D.J., Vijoen, F., Basei, M.A.S., VAlley, J.W. (2007) Zircons from kimberlite: new insights from oxygen isotopes, trace elements, and Ti in zircon thermometry. Geochimica et Cosmochimica Acta 71, 3887-3903.

PEARson, D.G., WitTig, N. (2014) The formation and evolution of cratonic mantle lithosphere - evidence from mantle xenoliths. In: Holland, H., Turekian, K. (Eds.) Treatise on Geochemistry. Second Edition, Elsevier, Amsterdam, Oxford, Waltham, 255-292.

Pearson, D.G., Brenker, F.E., Nestola, F., McNeill, J., Nasdala, L., Hutchinson, M.T., Matveev, S., Mather, K., Silvermit, G., Schmitz, S., Vekemans, B., VIncze, L (2014) Hydrous mantle transition zone indicated by ringwoodite included within diamond. Nature $507,221-224$

Russell, J.K., Porritt, L.A., LAVAllée, Y., Dingwell, D.B. (2012) Kimberlite ascent by assimilation-fuelled buoyancy. Nature 481, 352-356.

Tappe, S., Pearson, D.G., KJarsgaard, B.A., Nowell, G., Dowall, D. (2013) Mantle transition zone input to kimberlite magmatism near a subduction zone: origin of anaomalous $\mathrm{Nd}-\mathrm{Hf}$ isotope systematics at Lac de Gras. Earth and Planetary Science Letters 371-372, 235-251.

VAlley, J.W., KinnY, P.D., Schuklze, D.J., SpicuZZA, M.J. (1998) Zircon megacrysts from kimberlite: oxygen isotope variability among mantle melts. Contributions to Mineralogy and Petrology 133, 1-11.

Vervoort, J.D., PAtchett, P.J., Blichert-Toft, J., Albarède, F. (1999) Relationships between Lu-Hf and Sm-Nd isotopic systems in the global sedimentary system. Earth and Planetary Science Letters, 168, 79-99.

WU, F.-Y., YANG, Y.-H., MitchelL, R.H., Li, Q.-L., YANG, J.-H., ZHANG, Y.-B. (2010) In situ U-Pb age determination and Nd isotopic analysis of perovskites from kimberlites in southern Africa and Somerset Island, Canada. Lithos 115, 205-222. 